7. Лапін П.В. Економічна ефективність транспорту. Сер.: Економіка і управління. - 2015. пожежних поїздів: до постановки проблеми / - Вип. 31. - С. 78-90. П.В. Лапін // Збірник наукових праць Державного економіко-технологічного університету

Рецензент д.е.н., професор ДЕТУТ Ейтутіс Г.Д. Експерт редакційної колегії к.е.н., доцент УкрДУЗТ Токмакова І.В.

УДК 338.2:629.4

\title{
ФОРМУВАННЯ ПАТ «УКРАЇНСЬКА ЗАЛІЗНИЦЯ»: АНАЛІЗ МАЙНОВОГО ТА ФІНАНСОВОГО СТАНУ
}

\author{
Пилипенко О. В., к.е.н., доцент, професор, \\ Соколова Е. О., к.е.н., доцент, доцент (ДЕТУТ)
}

У статті проведено аналіз майнового та фінансового стану ПАТ «Украйнська залізниия» та виділено основні особливості його оцінки, щуо обумовлені специирікою виробничо-господарської $i$ фінансової діяльності «Укрзалізниці». Встановлено, щцо особливості оцінки вартості активів, технічного стану основних фондів та інтерпретації результатів аналізу фінансових коефіцієнтів впливають на коректність оцінки фінансово-економічного стану «Укрзалізниці» $і$ прогнозованість ефективності ї̈ функціонування у майбутньому.

Ключові слова: корпоратизація залізничного транспорту, оцінка майна, вартість основних засобів, ступінь зносу, фінансовий стан, платоспроможність.

\section{ФОРМИРОВАНИЕ ПАО «УКРЗАЛИЗНЫЦЯ»: АНАЛИЗ ИМУЩЕСТВЕННОГО И ФИНАНСОВОГО СОСТОЯНИЯ}

\author{
Пилипенко Е. В., к.э.н., доцент, \\ Соколова Э. А., к.э.н., доцент (ГЭТУТ)
}

В статье проведён анализ имущественного и финансового состояния ПАО «Украинская зализныця» и выделены особенности его оченки, обусловленные спецификой производственнохозяйственной и финансовой деятельности «Укрзализныци». Определено, что особенности оценки стоимости активов, технического состояния основных фондов и интерпретации результатов анализа финансовых коэффициентов влияют на корректность оценки финансово-экономического состояния «Укрзализныци» и прогнозируемость эффективности её функиионирования в будущем.

Ключевые слова: корпоратизация железнодорожного транспорта, оценка имущества, стоимость основных средств, степень износа, финансовое состояние, платёэсеспособность.

\section{THE FORMATION OF PJSC "UKRAINIAN RAILWAY": ANALYSIS OF PROPERTY AND FINANCIAL STATE}

\author{
Pylypenko O.V., PhD, associated professor,
}

Sokolova E.O., PhD, associated professor

(State Economic and Technological University of Transport)

Implementation of the reform and corporatization of railway transport of Ukraine caused the valuation of property (including non-current assets) of Railways and their structural divisions, whose 
property became authorized capital of Public Joint Stock Company "Ukrainian Railway" (short title is PJSC "Ukrzaliznytsia"). The article presents the analysis of property and financial state of PJSC "Ukrzaliznytsia" on the stage of its forming. The estimation of the value of non-current assets as well as analysis of the structure and the technical state of fixed assets of the Regional Branch of "South-West Railway" of PJSC "Ukrzaliznytsia" have been fulfilled in the paper. The authors have identified features of evaluation of property and financial state of "Ukrzaliznytsia" which are caused by the specifics of its production and economic and financial activities. The defined peculiarities of valuation of assets, technical condition of fixed assets and interpretation of results of analysis of financial ratios affect on the correct assessment of the financial and economic state of "Ukrzaliznytsia" and the predictability of the efficiency of its operation in the future.

Methods of research are grouping, expert evaluation, ratio analysis, structural analysis.

Keywords: corporatization of railway transport, evaluation of assets, the cost of fixed assets, the degree of fixed assets depreciation, the financial state, solvency.

Постановка проблеми. Питання оцінки майна і зокрема, основних засобів підприємств і відокремлених структурних підрозділів залізничного транспорту при формуванні статутного капіталу ПАТ «Українська залізниця» виявилось дискусійним, а процес оцінювання майна окремі експерти вважають непрозорим [1, 2]. Оскільки ПАТ «Укрзалізниця» $є$ найбільшим підприємством, вартість майна якого було оцінено за роки незалежності України, питання оцінки вартості майна та аналізу фінансовомайнового стану «Укрзалізниці» на момент корпоратизації $є$ надзвичайно актуальними.

Аналіз останніх досліджень і публікацій. Розробку методик аналізу фінансового та майнового стану та дослідження особливостей фінансової діяльності підприємств залізничного транспорту здійснювали Н. М. Колесникова, Н. І. Богомолова [3], О. О. Кравченко [4], I. Ю. Зайцева [5], К. А. Карачарова [6] та інші вітчизняні науковці. Дослідження сутності, ефективності та шляхів реформування i реструктуризації на залізничному транспорті виконували Г. Д. Ейтутіс [7], Г. Ю. Олійник [8] та багато інших. Однак, ці дослідження не стосуються питань оцінки майнового та фінансового стану підприємств залізничного транспорту в період корпоратизації; дослідження 3 питань теоретико-методологічних засад реструктуризації залізничного транспорту визначають передумови, етапи, сутність реструктуризації, особливості іiі проведення в Україні, але питання застосування конкретних методів оцінки майна залізничних підприємств (окрім констатації значного рівня технічного зносу основних засобів) залишились поза увагою.

Мета статті - дослідження особливостей проведення фінансового аналізу та оцінка майнового i фінансового стану ПАТ
«Укрзалізниця», філій та виробничих структурних підрозділів підприємства.

Викладення основного матеріалу. Особливості проведення та інтерпретації результатів аналізу фінансового стану для відокремлених підрозділів залізничного транспорту пояснюються специфікою ведення господарської діяльності підприємств і структурних підрозділів залізниць. Так, Укрзалізниця наділяє філії статутним капіталом, керуючі служби можуть передавати, оцінювати та переоцінювати основні засоби. Доходи від основної діяльності (перевезень, інших робіт) структурних підрозділів нараховуються в межах встановленого кошторису витрат, що обумовлює нульову рентабельність цих підрозділів за основними видами діяльності. Фінансові результати утворюються тільки за допоміжними та другорядними видами діяльності [3, 9]. Частина витрат основної діяльності можуть бути передані у служби, що викривляє їх величину та структуру [9]; дебіторська та кредиторська заборгованість виникають внаслідок взаєморозрахунків між службами і підрозділами [3].

Реструктуризація залізничного транспорту (як частина реформування [7]) направлена на формування нової структури управління галуззю, що повинно забезпечити утворення конкурентного середовища на залізничному транспорті, формування умов для росту самостійності господарюючих суб'єктів, підвищенні конкурентоспроможності та інвестиційної привабливості українських залізниць [10].

ПАТ «Українська залізниця», створене на базі 49 підприємств залізничного транспорту, розпочало свою діяльність 1 грудня 2015 р. [11]. Однак, ознайомлення 3 процесом формування ПАТ «Укрзалізниця» приводить нас до висновку, 
що замість реструктуризації мало місце об'єднання п'яти залізниць, окремих підприємств, що були в їх складі, відокремлених структурних підрозділів у єдину організацію. Активи частини шостої, Донецької залізниці на території, підконтрольній українському уряду, розподілені між Придніпровською та Південною залізницею [12]. При цьому залізниці та окремі підприємства, такі як УДЦТС «Ліски», ДП «УЦОП» втратили статус юридичних осіб. Зараз залізничний транспорт України представлений лише однією юридичною особою - ПАТ «Українська залізниця» [13, 14]. Статут Акціонерного товариства затверджено в розмірі 229,9 млрд грн. [14, ст. 36]. Міністерство інфраструктури України позиціонує структурні зміни в галузі як корпоратизацію та планує завершити процес за 2-3 роки. [15].

Проведення корпоратизації вимагало оцінки активів підприємств, що входитимуть до складу ПАТ, та формування статутного фонду товариства. На 1-е грудня 2015 р. були підготовлені розподільчі баланси підрозділів та регіональних філій, за якими від Укрзалізниці вони отримували основні засоби та інші активи, а товариству передали зареєстрований (статутний) капітал та інші види власного капіталу. Таким чином, зараз виробничі підрозділи не мають статутного капіталу, але у такому русі капіталів не має протиріччя із існуючим законодавством. Оскільки структурні підрозділи втратили статус відокремлених i наразі $€$ територіально віддаленими виробничими підрозділами (цехами) підприємства (без кодів ЄДРПОУ), то згідно 3 Господарським кодексом України такі підрозділи не мають у власності відокремленого/власного майна i, відповідно, можуть не мати відокремленого балансу; позбавлені права укладати (підписувати) будь-які угоди, в тому числі трудові; не мають рахунків в банках і права здійснювати фінансові операції. Це не стосується філій підприємства, наприклад, залізниць.

Таким чином, проведена корпоратизація суттєво ускладнила виконання поточної господарської діяльності виробничих підрозділів, які не можуть укладати договори та оплачувати послуги постачальників та підрядчиків, формувати штати та приймати на роботу співробітників тощо. Будь-які питання матеріально-технічного забезпечення такий підрозділ мусить вирішувати через органи ПАТ, отже, така структура управління $є$ дуже громіздкою та неефективною. До того ж на сьогодні відсутнє фінансування поточних потреб підрозділів галузі [16].

Отже, корпоратизація на даному етапі (ПАТ «Укрзалізниця» у такому вигляді функціонує лише три місяці) сприяла ще більшій монополізації залізничного транспорту, зумовила суперцентралізацію управлінських функцій, а тому не є ефективною. [17]. Формування нової організаційної структури відбулося шляхом злиття, що й зазначає англомовна презентація на сайті компанії [18] та про що свідчить посилення централізації управління і планування (замість сорока фінансових планів зараз у компаніі складають лише один [19]; відсутність планового документа як раз i зумовлює труднощі 3 фінансуванням підрозділів).

Перевагою утворення називають підвищення якості управлінських рішень та посилення відповідальності за їх розробку. Централізація функцій не означатиме одноосібне правління, оскільки керування тепер здійснює правління компанії, отже рішення приймаються колегіально, що підвищує їх прозорість та зменшує можливість корупції [19].

Можна виділити такі особливості оцінки майнового та фінансового стану, що суттєво ускладнюють розуміння реального стану (наявності, вартості, фізичного та морального зносу) майна Укрзалізниці, потреби у фінансових ресурсах та доступних джерелах фінансування.

1. Використання різних підходів до оцінки майна.

Активи (у т. ч. основні засоби, нематеріальні активи, незавершені капітальні інвестиції) наділені підрозділам Укрзалізницею за новою переоціненою вартістю. Майно (в т.ч. основні засоби) можуть бути оцінені кількома способами, що й зумовлює різні величини їх вартості (табл. 1).

Результати оцінки вартості активів, подані в табл. 1, мають такі особливості:

- вартість майна Укрзалізниці за оцінкою компаніï Deloitte перевищує вартість активів підприємства, встановлену в ході щорічних аудитів фінансової звітності і діяльності Укрзалізниці за оцінкою компанії «Ernst \& Young в Україні» [20] більше ніж утричі;

- відновна вартість або вартість умовно нових активів склала 1,253 трлн грн. Це вартість придбання або створення цих же або аналогічних активів, які сформували майно Укрзалізниці в цінах на 30.06. 2014 р., але отримана від компанії Deloitte у серпні 2015 р. [19]; 
- активи «Укрзалізниці» оцінені компанією Deloitte в 245 мільярдів гривень. Тобто $з$ двох оцінок компанії обрана менша через катастрофічно високий знос основних засобів залізниць, який становить майже $99 \%$ за окремими видами [1717]. Ця вартість активів була підтверджена Фондом Держмайна України $[11,19]$

\begin{abstract}
-оцінка, проставлена спеціалістами компанії «АРТ-Капітал» базується на вирахуванні чистого боргу з прибутку компанії та 3 досвіду практики оцінювання подібних компаній. Оцінку в 600 млн. доларів виставляють як найменшу 3 можливих, але не виключають i зростання вартості активів компанії до 2 і навіть 5,5 млрд дол. [2].
\end{abstract}

Таблиия 1

Вартість активів ПАТ «Укрзалізницяя за різними очінками, млрд грн

\begin{tabular}{|c|c|c|c|}
\hline Вид вартості & Оцінювач (виконавець) & Дата оцінки & Вартість активів \\
\hline Відновна вартість & \multirow{2}{*}{$\begin{array}{c}\text { Компанія “Deloitte" } \\
\text { (Deloitte Touche Tohmatsu } \\
\text { Ltd) }\end{array}$} & \multirow{2}{*}{$\begin{array}{l}\text { На } 31.07 .2014 \\
\text { (оцінка } \\
\text { здійснювалась у } \\
2015 \text { р.) }\end{array}$} & 1253 \\
\hline $\begin{array}{l}\text { Справедлива балансова } \\
\text { вартість на основі } \\
\text { прибуткового підходу }\end{array}$ & & & 245 \\
\hline $\begin{array}{l}\text { Балансова вартість, } \\
\text { встановлена за результатами } \\
\text { аудиту }\end{array}$ & $\begin{array}{c}\text { Компанія «Ernst \& Young } \\
\text { в Україні»» }\end{array}$ & На 30.06 .2015 & 73,7 \\
\hline $\begin{array}{l}\text { Балансова вартість за } \\
\text { результатами бухгалтерської } \\
\text { звітності }\end{array}$ & $\begin{array}{c}\text { Головне фінансове } \\
\text { управління УЗ }\end{array}$ & На 30.06.2015 & 133,6 \\
\hline Інвентаризаційна вартість & $\begin{array}{c}\text { Інвентаризаційні комісії, } \\
\text { комісія з приватизації }\end{array}$ & $\begin{array}{l}26.08 .2014- \\
11.09 .2014\end{array}$ & 11000 \\
\hline $\begin{array}{l}\text { Експертна вартість (за } \\
\text { мінусом чистих боргів) }\end{array}$ & «АРТ-Капітал» & 08.2015 & $\begin{array}{l}\text { \$600 млн, або } \\
15000\end{array}$ \\
\hline
\end{tabular}

Джерело: складено авторами на основі [2], [17], [19], [20].

Характерним $\epsilon$ те, що і фахівці компанії Deloitte, і експерти «АРТ-Капітал» зростання вартості майна «Укрзалізниці» пов’язують із зростанням тарифів на перевезення (до економічно обгрунтованих), отриманням компенсацій пільгових перевезень пасажирів 3 держбюджету. Названі заходи дозволять збільшити прибуток від операційної діяльності, відповідно зросте рентабельність та інвестиційна привабливість підприємства. "Укрзалізниця" в 2016 році без підвищення тарифів на вантажні перевезення може не отримати інвестицій для розвитку. Однак, в найближчій перспективі прогнози експертів навряд чи здійсняться, оскільки станом на лютий 2016 року Державна регуляторна служба не підтримала підвищення залізничних тарифів [21]. Але отримана оцінка активів все одно перевищує балансову, оскільки Deloitte вважає, що завдяки реформуванню Укрзалізниця як мінімум протягом п'яти років вийде на економічно обгрунтовані тарифи.

У табл. 2 подано показники вартості необоротних активів та технічного стану основних засобів Укрзалізниці.

Як видно 3 даних табл. 2, балансова вартість основних засобів за оцінкою аудиторської компанії суттєво нижча (щонайменше, - на $26 \%$ ), ніж за даними звітності. Такі відмінності в оцінці активів експерти пояснюють неефективним управлінням активами «Укрзалізниці», що знижує ії поточну прибутковість, а значить, негативно впливає на інвестиційну привабливість. [17].

Досить суттєво відрізняються і показники вартості необоротних активів за складовими та відсоток зносу основних засобів ПівденноЗахідної залізниці (найбільшої за протяжністю експлуатаційних колій - 21,6\% від загальної протяжності колій Укрзалізниці [11]), подані у табл. 3. 
Таблиия 2

Вартість необоротних активів Укрзалізниці, млн грн

\begin{tabular}{|c|c|c|c|}
\hline \multirow{3}{*}{ Активи } & \multicolumn{3}{|c|}{ За даними } \\
\hline & \multirow{2}{*}{$\begin{array}{c}\text { Фінансової звітності } \\
\text { на } 30.06 .2014 \text { р. }\end{array}$} & \multicolumn{2}{|c|}{ Аудиту «ЕҮ» станом на } \\
\hline & & $30.06 .2014 \mathrm{p}$. & $30.06 .2015 \mathrm{p}$. \\
\hline Необоротні активи, всього: & 94285,5 & 67502,2 & 65553,4 \\
\hline У т.ч.: & & & \\
\hline Основні засоби: & & & \\
\hline залишкова (балансова) вартість & 84562,8 & 62663,7 & 60768,6 \\
\hline первісна вартість & 6008878,5 & \multicolumn{2}{|c|}{$\mathrm{x}$} \\
\hline 3нос & 5924315,7 & \multicolumn{2}{|c|}{$\mathrm{x}$} \\
\hline Коефіцієнт зносу & 98,6 & \multicolumn{2}{|c|}{$\mathrm{x}$} \\
\hline Фінансові активи (фінансові інвестиції) & 263,7 & 206,4 & 111,9 \\
\hline $\begin{array}{l}\text { Відстрочені податкові активи та податки до } \\
\text { відшкодування }\end{array}$ & 4344,5 & 4632,1 & 4672,9 \\
\hline
\end{tabular}

Джерело: Таблицю складено за даними фінансової звітності «Укрзалізниці» та даними аудиторського висновку компанії «Ernst \& Young в Україні» («ЕY») [20].

Таблиия 3

Вартість майна, структура та стан основних засобів Південно-Західної залізнииі, млн грн

\begin{tabular}{|c|c|c|c|c|}
\hline \multirow[b]{2}{*}{ Показники вартості } & \multirow{2}{*}{$\begin{array}{c}\text { За даними } \\
\text { фінансової звітності }\end{array}$} & \multirow{2}{*}{$\begin{array}{l}\text { Оцінка } \\
\text { "Deloitte" }\end{array}$} & \multicolumn{2}{|c|}{ Питома вага, \% } \\
\hline & & & за балансом ПЗЗ & $\begin{array}{l}\text { за оцінкою } \\
\text { "Deloitte" }\end{array}$ \\
\hline 1 & 2 & 3 & 4 & 5 \\
\hline $\begin{array}{l}\text { Інвентаризаційна вартість майна*, } \\
\text { млрд грн }\end{array}$ & 2357,7 & - & $\mathrm{x}$ & $\mathrm{x}$ \\
\hline $\begin{array}{l}\text { Загальна ринкова вартість майна та } \\
\text { майнових прав }\end{array}$ & - & 52309,4 & $\mathrm{x}$ & 100,0 \\
\hline $\begin{array}{l}\text { Необоротні активи згідно } \\
\text { передавального балансу }\end{array}$ & 53038,6 & $\mathrm{x}$ & $\mathrm{x}$ & $\mathrm{x}$ \\
\hline $\begin{array}{l}\text { Необоротні активи за фінансовою } \\
\text { звітністю** }\end{array}$ & 21481,7 & - & 100,0 & $\mathrm{x}$ \\
\hline $\begin{array}{l}\text { У т. ч.: } \\
\text { Основні засоби: } \\
\text { - } \quad \text { залишкова вартість; } \\
\text { - первісна вартість; } \\
\text { - }\end{array}$ & $\begin{array}{c}19351,4 \\
2337436,3 \\
2318094,9\end{array}$ & 13724,4 & 90,0 & 26,2 \\
\hline $\begin{aligned} & \text { Нематеріальні активи: } \\
& \text { - } \text { балансова вартість } \\
& \text { - } \text { первісна вартість; } \\
& \text { - } \text { знос } \\
&\end{aligned}$ & $\begin{array}{l}23,9 \\
49,5 \\
25,6\end{array}$ & 35256,9 & 0,1 & 67,4 \\
\hline $\begin{array}{l}\text { Незавершені капітальні } \\
\text { інвестиції: } \\
\text { - } \text { за передавальним балансом; } \\
\text { - } \text { за балансом на } 30.06 .2015 \text { р. }\end{array}$ & $\begin{array}{l}4814,8 \\
2064,7\end{array}$ & $\begin{array}{c}3304,7 \\
-\end{array}$ & $\begin{array}{c}- \\
9,6\end{array}$ & 6,3 \\
\hline $\begin{array}{l}\text { Довгострокові фінансові } \\
\text { інвестиції }\end{array}$ & 10,3 & 18,9 & 0,0 & 0,0 \\
\hline Відстрочені податкові активи & 31,4 & 4,5 & 0,1 & 0,0 \\
\hline $\begin{array}{l}\text { Показники зносу (спрацювання), } \\
\text { \%: } \\
\text { - основних засобів } \\
\text { - нематеріальних активів }\end{array}$ & $\begin{array}{l}99,2 \\
51,7 \\
\end{array}$ & $\begin{array}{l}8,0 \\
x\end{array}$ & $\mathrm{x}$ & $\mathrm{x}$ \\
\hline
\end{tabular}

Джерела даних: [1], [22].

*Включає майно, що вноситься до статутного капіталу і майно, що закріплюється за правом господарського відання на 30.06. 2014 p.

** Станом на 30.06. 2015 p. 
Як випливає із наведених у табл. 3 даних, оцінка вартості майна (необоротних активів) Південно-Західної залізниці дуже відрізняється як за загальною сумою, так і за вартістю окремих складових. Звертає на себе увагу розбіжність у вартості нематеріальних активів, вартість яких оцінювачем майна - ТОВ «Делойт i Туш» оцінено майже утричі вище, ніж вартість основних засобів, і у 712 разів вище, ніж первісна вартість цих активів за бухгалтерським балансом. Очевидно, таку різницю викликала оцінка майнових прав залізниці, у т. ч. прав користування земельними ділянками. Структура необоротних активів Південно-Західної залізниці, складена згідно з оцінками «Делойт і Туш» та за фінансовою звітністю, абсолютна різна.

2. Некоректне визначення рівня зносу основних засобів.

Завдяки оцінці Deloitte основні засоби підприємства чарівним способом «помолодшали», тобто ступінь їх зносу зменшився. Таке покращення технічного стану основних засобів викликане тільки необхідністю нараховувати амортизацію та отримувати «інвестиційну складову» в тарифах. На сьогодні керівництво Укрзалізниці не бачить інших шляхів отримання інвестицій для оновлення та модернізації основних засобів, адже акції компанії залишаються в державній власності $[13$, 14], а значить отримати приватні інвестиції поки що буде неможливо.

До речі, експертами висловлюються сумніви щодо доцільності 100 \%-го державного акціонерного капіталу [16]. Нараховують три мінуси такого рішення: 1) витрати й інвестиції продовжує нести держава, отже, не зрозуміло, навіщо потрібно було акціонування i корпоратизація; 2) нема притоку додаткових джерел фінансування, якими могли б бути приватні інвестиції; 3) високий рівень корупції та неефективність господарських рішень на залізниці за державної власності збережеться. Однак, вважається що існує ймовірність продажу частини пакету акцій в майбутньому [2].

Інвентаризаційна вартість майна, що вноситься до балансу ПАТ «Українська залізниця» - майже 2,4 трлн грн, - у 45 разів перевищує оціночну вартість активів, виставлену оцінювачем «Делойт і Туш». У зв'язку з цим у звіті Рахункової палати України [1] зазначено, що Південно-Західна залізниця «...розглянувши попередні результати оцінки, проведеної ТОВ «Делойт i Туш», не погоджується 3 ними, оскільки останні $€$ необ'єктивними..., а тому $є$ неякісними. ...Оцінювальною компанією не оцінено такі об'єкти нерухомого майна, як модернізація верхньої будови колії, тобто залишкова вартість таких об'єктів прирівняна до 0 гривень. Це не відповідає дійсності, так як об'єкти переважно нові і по суті $\epsilon$ новою прокладеною колією взамін старої. Тільки по ПЧ4 не оцінено таких робіт на 95,0 млн. гривень. ...Не враховані зауваження підрозділівбалансоутримувачів щодо оцінки рухомого складу. Вагони, що повністю амортизовані i мають тільки ліквідаційну вартість, оцінено по 2,2 млн. гривень. Електровози, що обліковуються на балансах підрозділів локомотивної служби оцінені із заниженою вартістю». Керівництво Південно-Західної залізниці зауважує, що «...проведена ТОВ «Делойт і Туш» оцінки 3 порушенням вимог чинного законодавства України в частині об' єктивності, обгрунтованості та достовірності може призвести до невідповідності реальної вартості майна ринковій». [1]

Виробничі структурні підрозділи залізниць отримали за розподільчими балансами вартість активів, складену на основі оціночної вартості Deloitte. Не зважаючи на те, що первісна вартість основних засобів за оцінкою Deloitte нижча, ніж інвентаризаційна вартість, однак, враховуючи низький відсоток зносу - 7-8\% (табл. 3), балансова вартість основних засобів окремих підрозділів за новими балансами виявилась вищою. Щоб відповідно скорегувати баланси, у пасиві з'явився нерозподілений прибуток (ряд. 1420), якого у виробничих підрозділів по основній діяльності ніколи не було.

3. Недоцільність використання нормативних значень показників, що характеризують фінансовий стан галузі. Виробничо-господарська та фінансова діяльність Укрзалізниці має специфічні особливості, які не «вкладаються» у «нормальні» значення фінансових коефіцієнтів. Це наочно демонструють дані табл. 4.

Динаміка коефіцієнта автономії показує, що частка власних джерел коштів у загальних джерелах фінансування залишалась приблизно на одному рівні (58-59 \%) у 2011-2013 рр., але різко знизилась у 2014 р. - до $37 \%$. У 2015 р. ця тенденція продовжилась і на 30.06. 2015 р. власний капітал становив лише $31 \%$ від загальної суми пасивів, що менше рекомендованого нормативу - $50 \%$. Отже, на момент корпоратизації Укрзалізниця не мала фінансової автономії. 
Динаміка основних показників фінансового стану «Укрзалізниці»

\begin{tabular}{|l|c|c|c|c|c|}
\hline \multirow{2}{*}{ Показники } & \multicolumn{5}{c|}{ Роки } \\
\cline { 2 - 6 } & 2011 & 2012 & 2013 & 2014 & $\begin{array}{c}2015 \\
\text { (І півріччя) }\end{array}$ \\
\hline 1. Коефіцієнт автономії & 0,59 & 0,58 & 0,58 & 0,37 & 0,31 \\
\hline 2. -“-абсолютної ліквідності & 0,137 & 0,017 & 0,041 & 0,056 & 0,080 \\
\hline 3. -“-покриття & 0,414 & 0,287 & 0,388 & 0,180 & 0,181 \\
\hline $\begin{array}{l}\text { 4. Частка довгострокових зобов’язань в } \\
\text { сумі джерел коштів, \% }\end{array}$ & 17,6 & 18,2 & 20,9 & 12,8 & 7,9 \\
\hline $\begin{array}{l}\text { 5. Частка короткострокових зобов’язань, } \\
\text { \% }\end{array}$ & 23,5 & 23,7 & 21,2 & 49,5 & 48,8 \\
\hline 6. Операційна рентабельність, \% & 13,52 & 9,97 & 9,72 & 6,50 & 5,23 \\
\hline 7. Рентабельність активів, \% & 2,91 & 1,13 & 0,75 & $-20,91$ & $-6,39$ \\
\hline 8. Рентабельність власного капіталу, \% & 4,95 & 1,95 & 1,29 & $-55,48$ & $-7,18$ \\
\hline
\end{tabular}

Джерело: Розраховано авторами за даними офіційного сайту Укрзалізниці [20] у відповідності з методикою розрахунку показників, викладеною у [23, с. 170-189].

Рівень платоспроможності на основі ліквідності активів підприємства протягом аналізованого періоду залишається дуже низьким та не відповідає нормативним значенням. Разом 3 тим, коефіцієнт абсолютної ліквідності у 20122015 рр. має слабко виражену тенденцію до покращення. Значення коефіцієнтів ліквідності відображає специфіку структури активів залізничного транспорту, значна частка яких $€$ необоротними. Рівень покриття поточної кредиторської заборгованості також не відповідає нормативним значенням та різко погіршується у 2014-2015 pp., що стало результатом стрімкого збільшення поточної кредиторської заборгованості.

Так, частка короткострокових зобов'язань Укрзалізниці зросла у 2014 р. більше ніж удвічі до рівня 2013 р. - 3 21,2 до 49,5 \% загальної вартості усіх джерел фінансування та до 48,8 \% у першій половині 2015 р. Відповідно, частка довгострокових зобов'язань знизилась з 20,9 \% у 2013 р. до 12,8 \% у 2014 р. та до 7,9 \% - у першій половині 2015 р. Причиною таких зрушень у структурі позикових коштів $є$ нестача власних оборотних коштів для фінансування операційної діяльності, що примушувало Укрзалізницю залучати поточні кредити.

Різке збільшення частки короткострокових зобов'язань зумовлює значні видатки по обслуговуванню боргу та в умовах падіння курсу гривні приводить до утворення у 2014 р. чистих збитків від курсових різниць в сумі 14,2 млрд грн. [20]. 3 аналізу кредитного портфеля УЗ випливає, що $84 \%$ позикових коштів залучені у доларах США та євро за плаваючим курсом (LIBOR плюс відсоток) [18]. Оскільки У3 отримує доходи в основному у гривні, повертати борги підприємству надзвичайно важко через іiі знецінення. Унаслідок неплатоспроможності, обумовленої як внутрішніми, так і зовнішніми факторами, у травні 2015 р. оголошено технічний дефолт [2] та проведено реструктуризацію боргу (січень 2016 р.).

Показник рентабельності операційної діяльності Укрзалізниці за аналізований період має тенденцію до зниження. На показники рентабельності активів і власного капіталу Укрзалізниці негативно впливає існування чистого збитку від фінансової діяльності, пов'язаного 3 обслуговуванням кредитних зобов'язань [20], адже частка позикових коштів досягла 69 \% усіх джерел фінансування.

Як бачимо, показники аналізу фінансового стану характеризують різні аспекти діяльності та мають протилежні тенденції змін; залежні від неконтрольованих факторів зовнішнього середовища, що мають ймовірнісний характер політична та економічна стабільність економіки країни, динаміка валютних курсів тощо.

Фінансова криза та скорочення обсягів перевезень зумовлюють негативні тенденції змін показників фінансової незалежності, низьку платоспроможність, від'ємну рентабельність активів та власного капіталу. Кризу поглиблює складна політична та економічна ситуація в Україні. У результаті військової агресії Росії скоротились обсяги зовнішньої торгівлі, зменшився вантажообіг, а нових напрямів діяльності, за окремими виключеннями (наприклад, - Новий шовковий шлях) ще не напрацьовано. 
Висновки та перспективи подальших досліджень. Таким чином, при проведенні комплексного аналізу майнового і фінансового стану «Укрзалізниці» та Південно-Західної залізниці для правильного розуміння реальної ситуації необхідно враховувати існуючі особливості оцінки, а саме: по-перше, застосування консалтинговими агенціями різних підходів до оцінки майна залізничних підприємств, що перетворились у філії та виробничі підрозділи ПАТ «Укрзалізниця» в процесі корпоратизації; по-друге, некоректна оцінка рівня фізичного та морального зносу окремих елементів основних засобів ПАТ; потретє, неможливість використання «нормальних» (нормативних) значень фінансових коефіціснтів при аналізі фінансового стану Укрзалізниці через специфіку iï виробничо-господарської та фінансової діяльності.

Врахування зазначених особливостей дозволить підвищити об'єктивність та коректність оцінки фінансово-економічного стану ПАТ «Укрзалізниця» і прогнозованість потенційно можливих змін. Для подальшого удосконалення аналізу майнового і фінансового стану Укрзалізниці в умовах інституціональних перетворень слід: (1) розробити стратегію управління майном ПАТ «Укрзалізниця» на основі використання досвіду європейських залізниць, на яких процес реформування вже завершено; (2) розробити методичні підходи до оцінки фінансового стану підприємств в умовах підвищеної нестабільності ринкового середовища.

\section{СПИСОК ЛІТЕРАТУРИ}

1. Звіт про результати аудиту стану фінансово-господарської діяльності Державного територіально-галузевого об'єднання “ПівденноЗахідна залізниця". Рахункова палата України. / Затверджено рішенням Рахункової палати від 01.12.2015 № 10-4. - К.: 2015. [Електронний pecypc]. - Режим доступу: http://www.acrada.gov.ua/doccatalog/document/ 16747538/Zvit 10-4.pdf.

2. «Братська могила» для залізниці: Експерти «Дня» - про плюси й мінуси реформи галузі, оголошеної Кабміном. [Електронний pecypc]. - Режим доступу: http://www.day.kiev.ua/uk/article/ekonomika/bratska -mogyla-dlya-zaliznyci. [Назва з екрану].

3. Макаренко М. В. Основи управління фінансами залізничного транспорту: Навчальний посібник / М. В. Макаренко, Н.М. Колеснікова, Н.І. Богомолова та ін. - К.: ДЕТУТ, 2012. - 340 с.
4. Кравченко
O. O.
Стратегічний фінансовий план як сукупність пропорцій розвитку залізничного транспорту // Економічний форум: Науковий журнал. - 2016. № 1. - С. 312-321.

5. Зайцева I. Ю. Формування системи економічних показників, що характеризують фінансову складову економічної безпеки транспортних підприємств // Електронне наукове фахове видання «Ефективна економіка». - 2013, № 7. [Електронний ресурс]. - Режим доступу: http://www.economy.nayka.com.ua/?op=1\&z=2214
6. Карачарова
K. A.
Особливості формування фінансової стратегії підприємств залізничного транспорту // К. А. Карачарова // Вісник економіки транспорту і промисловості. 2015. - № 51. - С. 35-39.

7. Ейтутіс, Г. Теоретико-концептуальні засади реформування залізничного транспорту України / Г. Д. Ейтутіс, В. I. Сіраков // Залізничний транспорт України : науковопрактичний журнал. - 2009. - № 6. - С. 50-57.

8. Олійник Г. Ю. Теоретико-методологічні основи реструктуризації залізничного транспорту України // Електронне наукове фахове видання «Ефективна економіка». - 2014, № 4. [Електронний ресурс]. - Режим доступу:http://www.economy.nayka.com.ua/?op=1 $\& z=2972$.

9. Пилипенко О. В. Удосконалення управління витратами вагонного господарства залізниць України в умовах інституціональних змін / О. В. Пилипенко // Збірник наукових праць Державного економіко-технологічного університету транспорту. - 2014. - Вип. 28. - С. 79-87.

10. Концепція Державної програми реформування залізничного транспорту. Схвалено розпорядженням Кабінету Міністрів України від 27 грудня 2006 p. N 651-p. [Електронний ресурс]. - Режим доступу: http://zakon1.rada.gov.ua/laws/show/651-2006-p.

11. Публічне акціонерне товариство «Українська залізниця» [Електронний ресурс]. Режим доступу: https://uk.wikipedia.org/wiki/ Публічне_акціонерне_ товариство «Українська -залізниця»/

12. Кабмін розподілив майно Донецької залізниці між Південною i Придніпровською. [Електронний ресурс]. Режим доступу: http://www.theinsider.ua/business/54b3b5b84abf1/ 
13. Постанова Кабінету Міністрів України № 200 від 25.06.2015 р. «Про утворення публічного акціонерного товариства "Українська залізниця"». [Електронний ресурс]. - Режим доступу: http://zakon2.rada.gov.ua/laws/show/2002014-п.

14. Статут публічного акціонерного товариства "Українська залізниця" (Затверджено постановою Кабінету Міністрів України від 2 вересня 2015 р. № 735). [Електронний ресурс]. Режим доступу: http://zakon0.rada.gov.ua/laws/show/735-2015-п.

15. План заходів Укрзалізниці на 20152016 роки 3 реалізації Державної цільової програми реформування залізничного транспорту на 2010-2019 роки. Затверджено Наказом Укрзалізниці від 20.07.2015 № 237-Ц/од. [Електронний pecypc]. - Режим доступу: http://railway.lviv.ua/info/announcements/reforming/

16. «Укрзалізниця» стала акціонерним товариством. Що це змінить? [Електронний ресурс]. - Режим доступу: http:/hromadskeradio.org/ programs/na-svizhugolovu/ukrzaliznycya-stala-akcionernymtovarystvom-shcho-ce-zminyt [Назва з екрана].

17. Удосконалення механізмів реформування та розвитку залізничного транспорту в контексті реалізації структурних реформ в галузі. Аналітична записка / Національний інститут стратегічних досліджень. [Електронний pecypc]. - Режим доступу: http://www.niss.gov.ua/articles/1662/.
18. Ukrzaliznytsia: Investor presentation. [Електронний ресурс]. - Режим доступу: http://www.uz.gov.ua/files/file/about/investors/UZ\% $20-\% 20$ Investors $\% 20$ Presentation $\% 20$ -

$\% 20$ Final.pdf.

19. Кравцов, Е. Все объекты ж/д отрасли прошли оценку перед созданием АО "Украинская зализныця" (часть I). ЗМІ про Укрзалізницю. [Електронний ресурс]. - Режим доступу: http://www.uz.gov.ua/press_center

/ukrainian_railways__in_mass_media/412565/ [Назва з екрану].

20. Фінансові показники: Інформація для інвесторів. Офіційний сайт Укрзалізниці. [Електронний ресурс]. - Режим доступу: http://uz.gov.ua/files/file/about/investors/UZ $6 \mathrm{~m} 201$ 5 UKR v15 final.pdf.

21. Глава Держрегслужби виступила проти необгрунтованого підвищення тарифів на залізничні перевезення. [Електронний ресурс]. Режим доступу: http://24tv.ua/ n657226 [Назва 3 екрану].

22. Південно-Західна залізниця: Квартальна інформація емітента цінних паперів за 2 квартал 2015 року [Електронний ресурс]. Режим доступу: http://swrailway.gov.ua/file/article/126/24.07.2015.h tm.

23. Сич Є. М., Пилипенко О. В., Стасишен М. С. Стратегічний аналіз: Навч.метод. посіб.- К.: Каравела, 2010. - 304 с.

Рецензент д.е.н., професор ДЕТУТ Гудкова В.П. Експерт редакційної колегії к.е.н., дочент УкрДУЗТ Назаренко І.Л.

УДК 656.078

\title{
СУЧАСНІ ТЕНДЕНЦЇ̈ РОЗВИТКУ ТРАНСПОРТНО-ЛОГІСТИЧНИХ СИСТЕМ
}

\author{
Попова Н.В., к.е.н., доцент, зав. кафедри (ХТЕI КНТЕУ), \\ Шинкаренко В.Г., д.е.н., професор (ХНАДУ)
}

У статті розглядаються тендениії розвитку транспортно-логістичних систем світу в умовах глобалізаиії та інтеграційних процесів. Висвітлюються програми поліпшення транспортнологістичних систем, напрямки державної підтримки їх розвитку. Визначаються напрямки розвитку транспортно-логістичної системи України в умовах євроінтеграції, принципи державної політики в галузі транспорту, а також ефекти, які отримає економіка краӥни від інноваційного розвитку транспорту та логістики.

(C) Попова Н.В.,

Шинкаренко В.Г. 